\title{
DJERFISHERITE FROM UNALTERED KIMBERLITES OF THE UDACHNAYA-EASTERN PIPE, YAKUTIA
}

\author{
Victor V. Sharygin, Alexander V. Golovin, Nikolai P. Pokhilenko \\ Institute of Mineralogy and Petrography, UIGGM SD RAS, Novosibirsk, Russia
}

\section{INTRODUCTION}

Djerfisherite, $\mathrm{K}_{6} \mathrm{Na}(\mathrm{Fe}, \mathrm{Ni}, \mathrm{Cu})_{24} \mathrm{~S}_{26} \mathrm{Cl}$, firstly discovered in meteorites, later was found in $\mathrm{Cu}-\mathrm{Ni}$-ores, kimberlites, alkaline ultramafic and carbonatitic rocks, alkaline agpaitic rocks as well as in skarns around alkaline massifs. Clarke et al. (1994) summarized all data on occurrences and origins of djerfisherite. New information about the occurrences of this mineral given by Balabonin et al. (1980), Dawson et al. (1995), Barkov et al. (1997), Henderson et al. (1999) and Panina et al. (2001). Djerfisherite is very rare in kimberlites. This mineral was initially established in diamonds and xenoliths from kimberlites of Yakutia and South Africa as phase rimmed primary $\mathrm{Fe}-\mathrm{Ni}-\mathrm{Cu}-$ sulfides (Dobrovol'skaya et al., 1975; Clarke et al., 1977; Spetsius et al., 1987; Solov'yeva et al., 1988; Bulanova et al., 1990). Genesis of djerfisherite from these associations usually interprets as metasomatic transformation of xenoliths and diamonds due to introduction of $\mathrm{K}-\mathrm{Cl}-\mathrm{S}$-rich fluid either in the mantle prior to trapping by kimberlitic magma or at a late stage of kimberlite formation (Dobrovol'skaya et al., 1975; Spetsius et al., 1987; Bulanova et al., 1990; Clarke et al., 1994). Later djerfisherite was found in the groundmass of kimberlites from Northwest Territories (Canada) as late primary magmatic phase (Clarke et al., 1994; Chakhmouradian, Mitchell, 2001).

In this work, we describe a new occurrence of djerfisherite from unaltered kimberlitic rocks of the Udachnaya-Eastern pipe. Initially we found and analyzed djerfisherite from secondary melt inclusions in olivine of kimberlite breccias (Golovin et al., 2003). Later this mineral was observed in the groundmass of kimberlite breccias and veined monticellite kimberlites. This work is the first detailed description of djerfisherite from the groundmass of the Yakutian kimberlites. Previously this mineral was briefly mentioned only in the groundmass of kimberlite from one of the Yakutian pipes (Dobrovol'skaya et al., 1975).

\section{GEOLOGICAL BACKGROUND OF THE UDACHNAYA PIPE}

The Udachnaya pipe (Middle Paleozoic) is situated in the Daldyn-Alakit field of the Yakutian kimberlite province. It consists of two bodies (western and eastern), which are connected on the surface forming eight in plan. Upper-middle Cambrian and Lower Ordovician dolomites, dolomitic limestones, mudstones, sandstones, and calcareous conglomerates are the country sedimentary rocks of the Udachnaya pipe. The eastern diatreme was comprised at least by four intrusive phases: the three phases are different types of kimberlite breccias, the fourth phase is veined and dyke kimberlites (Khar'kiv et al., 1998). The studied kimberlite breccias and monticellite kimberlite are related to the main third and fourth stages, respectively. These rocks were exposed on the 350-650 $\mathrm{m}$ depth.

\section{MINERALOGY AND PETROGRAPHY}

Kimberlite breccias of the main third stage of the Udachnaya-Eastern diatreme contain abundant mantlederived xenocrysts and xenoliths as well as the crustal xenogenic material. Olivine and phlogopite are the main macrocrysts and phenocrysts in these rocks. Finegrained groundmass consists of olivine, calcite, phlogopite, perovskite, zoned spinel (chromite-Timagnetite-magnetite), ilmenite, djerfisherite and other sulfides, and possibly Ca-Na-carbonates. Monticellite kimberlite is the later intrusive phase than kimberlite breccias. In some cases it forms large blocks and injections in the Udachnaya-Eastern pipe (Kornilova et al., 1998). We studied the 2 cm-thick black veined injections of monticellitic rocks in the kimberlite breccia. The abundance of xenogenic material do not exceed 5 vol. \%. These rocks contain olivine and rare phlogopite as macro- or phenocrysts in fine-grained groundmass consisting of olivine, perovskite, phlogopite, monticellite, Ti-magnetite, sodalite, and djerfisherite. The secondary alterations are normally absent in all studied kimberlite species. According to $\mathrm{X}$-ray powder diffraction, all rocks contain also Na-Kchlorides, but their nature is unclear. Possibly they have post/late magmatic origin due to infiltration of Na-Ksolutions or melts in kimberlites. It should be also noted that djerfisherite is the dominant sulfide phase in these kimberlitic rocks. 

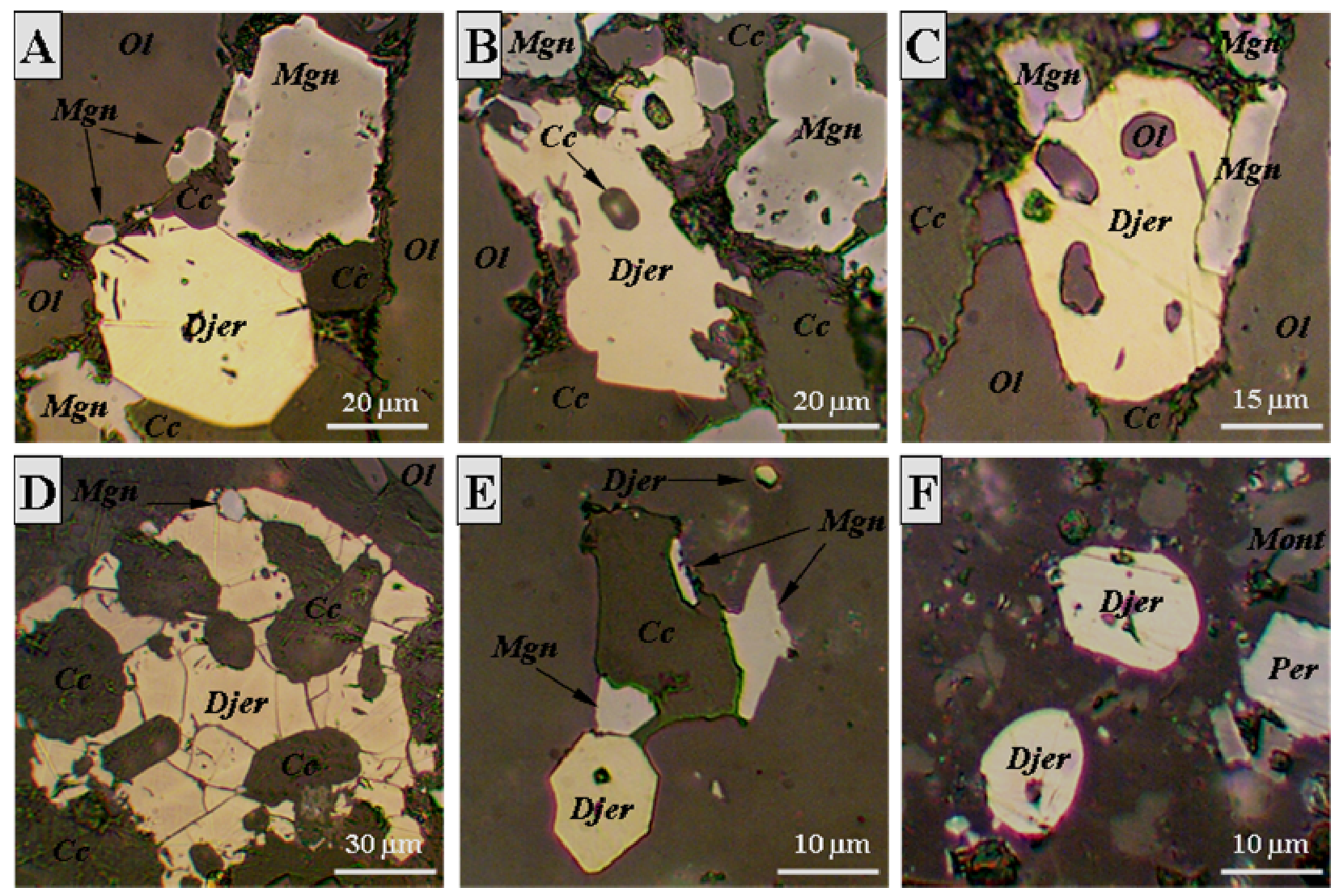

Figure 1. Djerfisherite from kimberlites of the Udachnaya-Eastern pipe (reflected light).

A-E - in kimberlite breccia: A - polygonal grain in groundmass in association with zoned spinel (core - Cr-spinel, middle - Timagnetite, rim - magnetite), olivine-2 and calcite; B - xenomorphic isolation with calcite inclusion; $\mathbf{C}-$ grain with olivine inclusions; D - xenomorphic isolation with calcite inclusions; $\mathbf{E}-$ secondary polycrystalline inclusion (calcite + magnetite + djerfisherite) in the outer zone of olivine-1; F - rounded blebs of djerfisherite in association with monticellite and perovskite inclusions in poikilitic sodalite from monticellite kimberlite.

Symbols: Djer - djerfisherite; Mgn - zoned spinel; Ol - olivine; Cc - calcite; Mont - monticellite; Per - perovskite.

\section{OCCURRENCE OF DJERFISHERITE IN THE UDACHNAYA-EASTERN PIPE}

Djerfisherite in the groundmass of kimberlite breccia is the latest mineral phase. It either forms individual subhedral grains (up to $50-100 \mu \mathrm{m}$ ) in association with magnetite and rarely with pyrrhotite or fills the interstitial space between other groundmass minerals. Olivine, calcite and other groundmass minerals occur as crystal inclusions in the grains of djerfisherite (Fig. 1 A-D).

$\mathrm{K}$-sulfide is also observed in the secondary inclusions, which forms trails in the xenocrystal olivine, rarely - in the groundmass olivine of kimberlite breccia. In this mineral djerfisherite occurs as individual sulfide blebs (up to $30 \mu \mathrm{m}$ ) and as a daughter phase in the secondary melt and polycrystalline inclusions $(5-80 \mu \mathrm{m})$. In melt inclusions it is associated with carbonates, silicates (tetraferriphlogopite, olivine, humite-clinohumite, diopside), magnetite, Na-K chlorides and sulfates, rarely - with Ni-rich pyrrhotite $(4.4 \mathrm{wt} \% \mathrm{Ni})$. Ti-poor magnetite and djerfisherite are closely associated in the melt inclusions. The size of inclusion djerfisherite grains ranges from 2 to $15 \mu \mathrm{m}$. Homogenization of melt inclusions occurred at $700-800^{\circ} \mathrm{C}$, and they were trapped at shallow depth (Golovin et al., 2003). During heating djerfisherite and magnetite disappeared near homogenization temperatures. Polycrystalline inclusions contain the association calcite + magnetite + djerfisherite (Fig. $1 \mathrm{E}$ ).

In monticellite kimberlite djerfisherite forms rounded isolations (up to $20 \mu \mathrm{m}$ ) in the groundmass or sulfide blebs in poikilitic sodalite together with monticellite, perovskite, and magnetite (Fig. 1 F). 


\section{Table 1: Some representative compositions of djerfisherite from kimberlites of the Udachnaya-Eastern pipe}

$\begin{array}{llllllllllll}\text { Sample } & \mathbf{1} & \mathbf{2} & & \mathbf{3} & \mathbf{4} & \mathbf{5} & & \mathbf{6} & \mathbf{7} & & \mathbf{8} \\ \mathbf{w t .} \% & & \mathbf{C} & \mathbf{r} & & & \mathbf{c} & \mathbf{r} & & \mathbf{c} & \mathbf{r} & \\ \mathbf{K} & 8,94 & 9,07 & 9,00 & 9,01 & 9,30 & 9,15 & 9,14 & 9,10 & 9,25 & 9,28 & 9,14 \\ \mathbf{N a} & 0,08 & 0,05 & 0,05 & 0,07 & 0,09 & 0,00 & 0,00 & 0,00 & 0,00 & 0,00 & 0,00 \\ \mathbf{F e} & 34,82 & 35,98 & 35,96 & 32,56 & 42,79 & 38,86 & 38,80 & 38,99 & 42,13 & 42,13 & 38,07 \\ \mathbf{N i} & 4,20 & 15,16 & 15,54 & 23,09 & 1,97 & 4,79 & 4,75 & 6,30 & 6,32 & 6,33 & 7,55 \\ \mathbf{C o} & 0,17 & 0,30 & 0,34 & 0,50 & 0,19 & 0,32 & 0,33 & 0,49 & 0,20 & 0,19 & 0,17 \\ \mathbf{C u} & 17,56 & 5,21 & 4,88 & 0,06 & 10,66 & 12,82 & 12,76 & 11,33 & 7,54 & 7,37 & 10,00 \\ \mathbf{S} & 32,81 & 32,85 & 32,88 & 33,09 & 33,18 & 32,84 & 32,91 & 32,68 & 33,11 & 33,15 & 33,37 \\ \mathbf{C l} & 1,35 & 1,25 & 1,32 & 1,29 & 1,33 & 1,40 & 1,30 & 1,29 & 1,38 & 1,37 & 1,45 \\ \text { Total } & 99,93 & 99,87 & 99,97 & 99,67 & 99,51 & 100,18 & 99,99 & 100,18 & 99,93 & 99,82 & 99,75 \\ & & & & & & & & & & & \\ \text { K } & 5,81 & 5,89 & 5,84 & 5,81 & 5,98 & 5,94 & 5,92 & 5,94 & 5,96 & 5,97 & 5,84 \\ \mathbf{N a} & 0,09 & 0,06 & 0,06 & 0,08 & 0,10 & 0,00 & 0,00 & 0,00 & 0,00 & 0,00 & 0,00 \\ \mathbf{F e} & 15,84 & 16,35 & 16,32 & 14,69 & 19,25 & 17,66 & 17,60 & 17,81 & 18,99 & 18,97 & 17,03 \\ \mathbf{N i} & 1,82 & 6,55 & 6,71 & 9,91 & 0,84 & 2,07 & 2,05 & 2,74 & 2,71 & 2,71 & 3,21 \\ \mathbf{C o} & 0,07 & 0,13 & 0,14 & 0,21 & 0,08 & 0,14 & 0,14 & 0,21 & 0,09 & 0,08 & 0,07 \\ \mathbf{C u} & 7,02 & 2,08 & 1,95 & 0,02 & 4,21 & 5,12 & 5,09 & 4,55 & 2,99 & 2,92 & 3,93 \\ \mathbf{S} & 26,00 & 26,00 & 26,00 & 26,00 & 26,00 & 26,00 & 26,00 & 26,00 & 26,00 & 26,00 & 26,00 \\ \mathbf{C l} & 0,97 & 0,89 & 0,94 & 0,92 & 0,94 & 1,00 & 0,93 & 0,93 & 0,98 & 0,97 & 1,02\end{array}$

1-3 - from inclusions in olivine xenocrysts from kimberlite breccia; 4-6 - from groundmass of kimberlite breccia; 7-8 - from groundmass of monticellite kimberlite. $\mathbf{c}$ - core, $\mathbf{r}$ - rim of grain. Formula calculated on the basis of $\mathrm{S}=26$.

\section{MINERAL CHEMISTRY}

\section{ANALYTICAL METHODS}

A CAMEBAX electron microprobe equipped with an energy-dispersion system at the United Institute of Geology, Geophysics and Mineralogy, Novosibirsk was used for analyses. Operating conditions were accelerating voltage $20 \mathrm{kV}$, beam current $15-30 \mathrm{nA}$, beam diameter $c a .2 \mu \mathrm{m}$, counting time 30 seconds. The accuracy for major elements is about $2.0 \%$ relative. Mineral standards and synthetic alloys were used for controls: chalcopyrite and pyrrhotite for $\mathrm{Fe}$, $\mathrm{Cu}$ and $\mathrm{S}$, synthetic Fe-Ni-Co alloy for $\mathrm{Ni}$ and $\mathrm{Co}$, albite for $\mathrm{Na}$, sanidine for $\mathrm{Si}, \mathrm{Al}$ and $\mathrm{K}$, chlorapatite for $\mathrm{Cl}$. Ag, $\mathrm{Tl}$ and $\mathrm{Li}$ were not determined in djerfisherite. The grains with size more than $10 \mu \mathrm{m}$ were selected for microprobe analysis.

\section{CHEMICAL COMPOSITIONS}

The broad compositional ranges are most characteristic for djerfisherite from inclusions in olivine of kimberlite breccia (based on 26 analyses, in wt. \%): Fe - 32.6-
38.8; $\mathrm{Ni}-4.2-23.1 ; \mathrm{Co}-0.2-0.5 ; \mathrm{Cu}-0.1-17.6 ; \mathrm{K}-$ 8.9-9.3; $\mathrm{Na}-0.04-0.7 ; \mathrm{S}-32.5-33.4 ; \mathrm{Cl}-1.2-1.4$. However, the variations in $\mathrm{Fe}, \mathrm{Ni}$ and $\mathrm{Cu}$ are insignificant within single grains from the core to rim. In general, djerfisherites from the groundmass of kimberlite breccia and monticellite kimberlite are richer in $\mathrm{Fe}$ and poorer in $(\mathrm{Ni}+\mathrm{Co})$ than mineral of olivine-hosted inclusions. The core-to-rim deviations within single grains are also minimal. Thus, djerfisherite from groundmass of kimberlite breccia has the following compositional variations (based on 57 analyses, in wt. \%): $\mathrm{Fe}-37.0-42.7$; $\mathrm{Ni}-2.0-6.3$; $\mathrm{Co}-$ 0.2-0.4; $\mathrm{Cu}$ - 9.9-14.9; K - 8.8-9.4; Na - 0-0.2; $\mathrm{S}-$ 32.6-33.3; $\mathrm{Cl}-1.2-1.5$. Potassium sulfide from groundmass of monticellite kimberlite is characterized by lower $\mathrm{Cu}$ and higher $\mathrm{Ni}$ (based on 22 analyses, in wt. \%): $\mathrm{Fe}-38.1-43.5$; $\mathrm{Ni}-5.8-7.9$; $\mathrm{Co}-0.15-0.22$; $\mathrm{Cu}-6.1-10.0 ; \mathrm{K}-9.1-9.4 ; \mathrm{S}-33.1-33.4 ; \mathrm{Cl}-1.3-1.5$. Table 1 presents some representative compositions of djerfisherite from different rock species of the Udachnaya-Eastern pipe. These data show that $\mathrm{Cl}$ is an essential component of djerfisherite at approximate level of one atom per formula unit and $\mathrm{Na}$ is not very significant element (excepting some djerfisherites from inclusions). 


\section{DISCUSSION}

The variation diagrams (Fig. 2) show the pronounced differences between djerfisherites from olivine-hosted inclusions and groundmass of kimberlite breccias and monticellite kimberlites. Djerfisherite from kimberlite breccia groundmass forms two compositional clusters in the $\mathrm{Cu}$ abundance. The first cluster overlaps with some djerfisherite compositions from olivine-hosted inclusions. Possibly it is evidenced that some djerfisherites from inclusions may be result of the invasion of residual kimberlite melt, which forms the groundmass of kimberlite breccias. Other djerfisherites probably originate due to complete replacement of primary sulfides in olivine xenocrysts. In general, djerfisherites from groundmass of kimberlite breccias and monticellite kimberlite show negative correlations between $\mathrm{Cu}$ and $\mathrm{Fe}$ evidencing about possible isomorphism of these elements in the djerfisherite structure. Moreover, there are no clear correlations between $\mathrm{Cu}$ and $(\mathrm{Ni}+\mathrm{Co})$. Unlike groundmass, djerfisherites from olivine-hosted inclusions have negative correlation between $\mathrm{Cu}$ and $(\mathrm{Ni}+\mathrm{Co})$.

The compositional data on djerfisherite from kimberlites of the Udachnaya-Eastern pipe have compared with literature compositions for K-sulfide from sulfide associations in diamonds and xenoliths from the Yakutian kimberlites as well as from groundmass of kimberlites at Elwin Bay (Dobrovol'skaya et al., 1975; Spetsius et al., 1987; Solov'yeva et al., 1988; Bulanova et al., 1990; Clarke et al., 1994). Majority of djerfisherites from the Udachnaya-Eastern pipe generally fall in the compositional fields of this mineral from the Yakutian diamonds and xenoliths (Fig. 2). Djerfisherite from kimberlite groundmass of this pipe are richer in $\mathrm{Cu}$ than K-sulfide from kimberlite groundmass at Elwin Bay (Clarke et al., 1994).

The data obtained show that djerfisherite in unaltered kimberlites of the Udachnaya-Eastern pipe is a late primary magmatic mineral belonging to the stage of crystallization of groundmass. During formation of kimberlite breccias the kimberlitic melt due to phenocryst crystallization evolved towards carbonatitic compositions (Golovin et al., 2003). Crystallization of carbonates from volatile-rich silicate-carbonate melt probably permits djerfisherite to be stable. It should be noted that djerfisherite and other potassium sulfides are common late phases for volcanic and intrusive carbonatites and related alkaline silicate rocks (Balabonin et al., 1980; Dawson et al., 1995; Henderson et al., 1999; Panina et al., 2001).
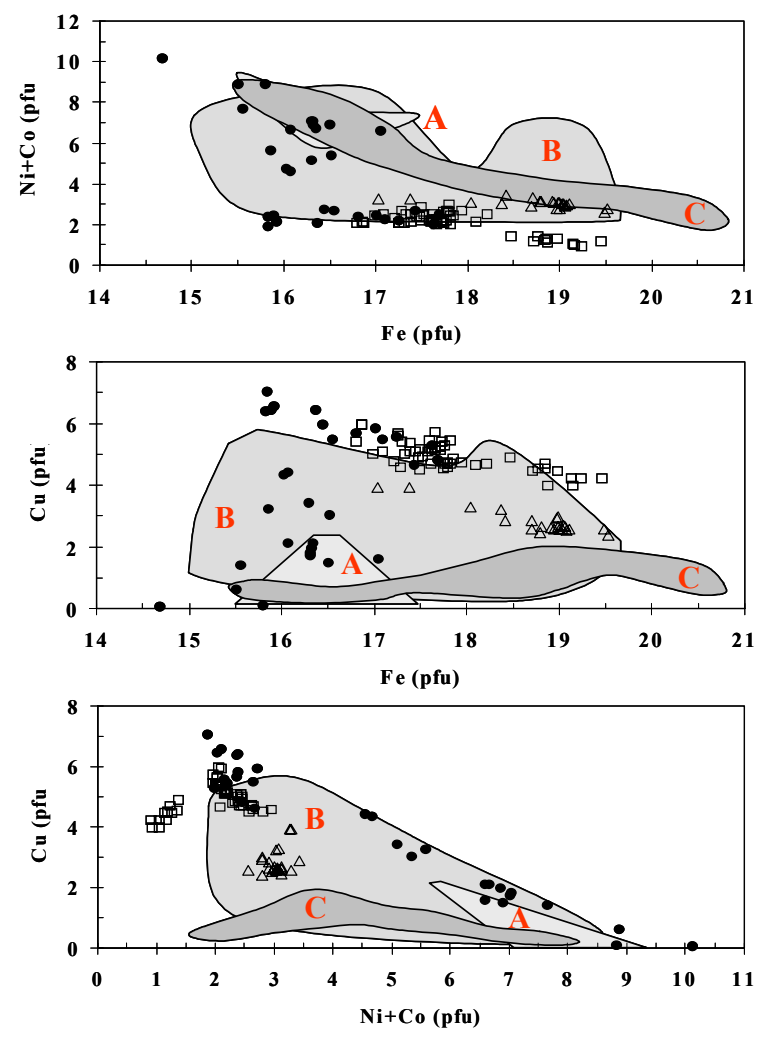

Figure 2. Compositional variations of djerfisherite (in apfu) from kimberlites of the Udachnaya-Eastern pipe.

Solid circles - from inclusions in olivine of kimberlite breccia; open squares - from groundmass of kimberlite breccia; open triangles - from groundmass of monticellite kimberlite. Compositional fields of djerfisherite: $\mathbf{A}$ - from primary sulfide inclusions in diamonds of Yakutia (Bulanova et al., 1990); B - from sulfide associations in deep-seated xenoliths from the Yakutian kimberlites (Dobrovol'skaya et al., 1975; Spetsius et al., 1987; Solov'yeva et al., 1988; Bulanova et al., 1990); C - from groundmass of the Elwin Bay kimberlites (Clarke et al., 1994).

Monticellite kimberlite principally differs in chemical and mineral composition of the groundmass from kimberlite breccia in particular due to the absence of carbonates and the appearance of monticellite and sodalite. Kornilova et al. (1998) interpreted monticellite kimberlite as crystallization product of evolved kimberlite melt, which possibly assimilated evaporites from the country sedimentary rocks around the Udachnaya pipe. Apparently, the assimilation may be possible to explain the appearance of such Cl-rich mineral as sodalite. The different trends for residual portions of kimberlitic melt were likely to determine the differences in composition of djerfisherites from the particular kimberlite species of the Udachnaya pipe.

The comparison of chemical data on djerfisherite from mantle-derived xenoliths and host kimberlites allow us to make some suggestions about the origin of this 
sulfide in xenoliths and xenocrysts. Previous investigations (Dobrovol'skaya et al., 1975; Clarke et al., 1977; Spetsius et al., 1987; Solov'yeva et al., 1988; Bulanova et al., 1990) directly showed that djerfisherite is normally secondary after primary mantle sulfides due to interaction of metasomatizing fluid/melt. However, in most cases it is unclear what source of metasomatizing agent and what P-T-conditions for its interaction on the primary sulfides. At present day two dominant points of view exist: (1) metasomatic event occurred in the mantle prior to entrapment by kimberlitic melt (Dobrovol'skaya et al., 1975; Clarke et al., 1977; Spetsius et al., 1987; Solov'yeva et al., 1988); (2) metasomatism took place during the transportation of xenolith. To our mind, djerfisherite in diamonds and xenoliths from kimberlites may be product of the reaction between evolved kimberlitic melt or fluid and primary sulfides at shallow depth conditions. Namely, metasomatizing agent acted on xenocryst/xenolith might be kimberlitic melt itself or its fluids. In the case of the primary sulfide inclusions in diamonds and minerals of mantle-derived xenoliths, where djerfisherite forms outer rims, it may suggest the penetration of this fluid/melt by microfractures, which occur around the inclusions after crystallization and transformation of sulfide melt (Bulanova et al., 1990). For the mantle sulfide associations occurring in intergranular space of xenoliths it may assume not only reactionary nature of djerfisherite, but and its crystallization from kimberlitic melt itself. In this case the primary sulfides, especially pentlandite owing to the similarities of the crystal structures (Evans, Clark, 1981), might be the basis for crystallization of djerfisherite from residual kimberlitic melt penetrating into xenolith by intergranular space.

This work was supported by Russian Foundation of Basic Research (grants nos. 02-05-64620 и 00-1598541).

\section{REFERENCES}

Balabonin, N.L., Voloshin, A.V., Pakhomovskii, Y.A., Polyakov, K.I., 1980. The composition of djerfisherite from alkaline complexes, Kola Peninsula. Mineral. Zh., 2, 90-99 (in Russian).

Barkov, A.Y., Laajoki, K.V.O., Gehör, S.A., Yakovlev, Yu.N., Taikina-Aho, O., 1997. Chlorine-poor analogues of djerfisherite - thalfenisite from Noril'sk, Siberia and Salmagorsky, Kola Peninsula, Russia. Can. Mineral., 35, 1421-1430.

Bulanova, G.P., Spetsius, Z.V., Leskova, N.V., 1990. Sulfides in diamonds and xenoliths from kimberlitic pipes of Yakutia. Publ. H. Nauka, Novosibirsk, 120 pp. (in Russian).
Chakhmouradian, A.R., Mitchell, R.H., 2001. Three compositional varieties of perovskite from kimberlite of the Lac de Gras field (Northwest Territories, Canada). Mineral. Mag., 65, 133-148.

Clarke, D.B., Mitchell, R.H., Chapman, C.A.T., MacKay, R.M., 1994. Occurrence and origin of djerfisherite from the Elwin Bay kimberlite, Somerset Island, Northwest Territories. Can. Mineral., 32, 815-823.

Clarke, D.B., Pe, G.G., MacKay, R.M., Gill, K.R., O'Hara, M.J., Gard, J.A., 1977. A new potassium - iron nickel sulfide from a nodule in kimberlite. Earth Planet. Sci. Lett., 35, 421-428.

Dawson, J.B., Smith, J.V., Steele, I.M., 1995. Petrology and mineral chemistry of plutonic igneous xenoliths from the carbonatite volcano, Oldoinyo Lengai, Tanzania. J. Petrol., 36, 797-826.

Dobrovol'skaya, M.G., Tsepin, A.I., Ilupin, I.P., Ponomarenko, A.I., 1975. Djerfisherite from the Yakutian kimberlites. In: Tamarinov, P.M. (Ed.), Mineraly i Paragenezisy Mineralov Endogennykh Mestorozhdenii. Publ. H. Nauka, Leningrad, 3-11 (in Russian).

Evans, H.T., Clark, J.R., 1981. The crystal structure of bartonite, a potassium iron sulfide, and its relationship to pentlandite and djerfisherite. Am. Mineral., 66, 376-384.

Golovin, A.V., Sharygin, V.V., Pokhilenko, N.P., Mal'kovets, V.G., Kolesov, B.A., Sobolev, N.V., 2003. Secondary melt inclusions in olivine from unaltered kimberlites of the Udachnaya-Eastern pipe, Yakutia. Dokl. Acad. Sci., 388, 369-372 (in Russian).

Henderson, C.M.B., Kogarko, L.N., Plant, D.A., 1999. Extreme closed system fractionation of volatile-rich, ultrabasic peralkaline melt inclusions and the occurrence of djerfisherite in the Kugda alkaline complex, Siberia. Mineral. Mag., 63, 488-495.

Khar'kiv, A.D., Zinchuk, N.N., Kryuchkov, A.I., 1998. Diamond primary deposits of the world. Publ. H. Nedra, Moscow, 555 pp. (in Russian).

Kornivola, V.P., Egorov, K.N., Safronov, A.F., Filippov, N.D., Zaitsev, A.I., 1998. Monticellite kimberlite from the Udachnaya-Eastern pipe and some aspects for evolution of kimberlite melts. Otech. Geol., no. 1, 4851 (in Russian).

Panina, L.I., Sazonov, A.M., Usol'tseva L.M., 2001. Meliliteand monticellite-bearing rocks of the Krestovskay intrusion (northern Siberian Platform) and their genesis. Russ. Geol. Geophys., 42 (9), 1314-1332.

Solov'yeva, L.V., Barankevich, V.G., Zav'yalova, L.L., Lipskaya, V.I., 1988. Metacomatic alterations in ferromagnesian eclogites from the Udachnaya pipe. Dokl. Acad. Sci. USSR, Earth Sci. Sect., 303, 107110.

Spetsius, Z.V., Bulanova, G.P., Leskova, N.V., 1987. Djerfisherite and its genesis in kimberlitic rocks. Dokl. Acad. Sci. USSR, Earth Sci. Sect., 293, 133136.

Contact: VV Sharygin, Institute of Mineralogy and

Petrography, Koptyuga prospect 3, 630090 Novosibirsk,

Russia, E-mail: sharygin@uiggm.nsc.ru 